Jurnal Ilmu Dan Teknologi Kesehatan

Vol 7, No 2, Maret 2020,

ISSN: 2338-9095 (Print)

ISSN: 2338-9109 (online)

\title{
Basic Construction Factors of Participatory Asset Community Development Health In Action (Yudhia) Model to Prevent Complication of Pregnancy and Child-Birth
}

\author{
Yudhia Fratidhina ${ }^{1}$, Nursyirwan Effendi ${ }^{2}$, Rizanda Machmud ${ }^{2}$, Artha Budi Duarsa ${ }^{3}$ \\ ${ }^{1}$ Poltekkes Kemenkes Jakarta III, Indonesia, ${ }^{2}$ Department of Public Health Andalas \\ University Padang, Indonesia, ${ }^{3}$ Faculty of Medical, Al Azhar University Mataram, Indonesia \\ Email:yudhiaf@yahoo.com
}

\section{Article history}

Posted, Sept 26th, 2019

Reviewed, Feb 25th, 2020

Received, March 10th, 2020

\begin{abstract}
High Maternal Mortality Rate (MMR) is mostly caused by a lack of information and a bad habit of pregnant women in high-risk pregnancy treatment. This condition causes an impact to high maternal mortality during childbirth. This study has aims to identify factors as the main construction of the Participatory Asset Community Development Research Action Model (YUDHIA). This study used a qualitative approach. The location of the study is at Cimanuk, Pandeglang, Banten. Informants were chosen based on purposive sampling and snowball techniques. Key informants were four pregnant women that had complication risk. Supporting informants were eight-person. Data collecting used in-depth interviews and recorded by a tape recorder. Analysis data used RAP techniques and released 12 themes that described the main factors in the construction of the YUDHIA model. The description was (1) development of community assets, such as physical, economic, environmental, human, and social assets. (2) Community participation, such as the dimension of community contribution, community development, and organization. This study is community participation has been already existed by forming desa siaga (standby village). The most crucial asset in the community is human assets, midwifery, and dukun (traditional birth attendant), therefore create a strong commitment to giving priority to the needs and lives of pregnant women.
\end{abstract}

Keywords: community assets; community participation; YUDHIA model

\begin{abstract}
ABSTRAK
Angka Kematian Ibu (AKI) yang tinggi sebagian besar disebabkan oleh kurangnya informasi dan kebiasaan buruk ibu hamil dalam perawatan kehamilan risiko tinggi. Kondisi ini berdampak pada tingginya angka kematian ibu saat melahirkan. Penelitian ini bertujuan untuk mengidentifikasi faktor-faktor sebagai konstruksi utama model pendampingan partisipatif melalui pemberdayaan masyarakat dan pemanfaatan aset di masyarakat untuk pencegahan komplikasi kehamilan dan persalinan (YUDHIA). Penelitian ini menggunakan pendekatan kualitatif. Lokasi penelitian adalah di Cimanuk, Pandeglang, Banten. Informan dipilih berdasarkan teknik purposive sampling dan bola salju. Informan kunci adalah empat wanita
\end{abstract}


hamil yang memiliki risiko komplikasi. Informan pendukung adalah delapan orang. Pengumpulan data menggunakan wawancara mendalam dan direkam dengan tape recorder. Analisis data menggunakan teknik RAP, dan merilis 12 tema yang menggambarkan faktor utama dalam pembangunan model YUDHIA. Uraian tersebut adalah (1) pengembangan aset masyarakat, seperti aset fisik, ekonomi, lingkungan, manusia, dan sosial. (2) Partisipasi masyarakat seperti dimensi kontribusi masyarakat, pengembangan masyarakat dan organisasi. Penelitian ini adalah partisipasi masyarakat telah ada dengan membentuk desa siaga. Aset yang paling penting di masyarakat adalah aset manusia, kebidanan dan dukun bayi, oleh karena itu menciptakan komitmen yang kuat untuk memberikan prioritas kebutuhan dan kehidupan wanita hamil.

Kata kunci : aset komunitas; partisipasi komunitas; model YUDHIA

\section{INTRODUCTION}

Maternal Mortality Rate (MMR) is one of the critical indicators of the level of public health and able to be used in the monitoring of pregnancy-related deaths. This indicator is affected by general health status, education, and services during pregnancy and childbirth (Yasa, 2012; Kemenkes RI, 2019). The direct causes of maternal mortality for more than $90 \%$ are a result of obstetric complications, mainly of childbirth complications (Walker, Permezel and Berkovic, 2009; Gong et al., 2012).

Based on reports from the Provincial Health Office of Banten, the highest MMR was in Pandeglang. Complications of pregnancy and childbirth in Pandeglang district caused 34 cases of maternal mortality in 2013, bleeding was 14 cases, hypertension during pregnancy was 8 cases, the infection was 4 cases, and prolonged childbirths is nothing. Another reason was 9 cases (Pandeglang, 2016).

One of the strategic efforts in improving the knowledge, awareness, and motivation towards improved behavior for the prevention of complications of pregnancy and childbirth. This can be conducted through the empowerment and participation of family or community. Participation is a voluntary involvement by the community in self-determined changes, it also means the community involvement in self-development, life, and their environment (Mikkelsen, 2011; Kulkarni, 2016). Community empowerment goal is to enable communities to determine practices/actions in solving problems and managing the planned activities, with an increase in the capacity of individuals, control efforts, institutional and environmental improvement (Mardianto, 2013; Kasmel and Andersen, 2011). The empowerment goal is to increase the 
capacity and capability of society to be able to recognize the encountered problems, explore, and exploit the available resources, as well as show their existence clearly (Yasa, 2012; Samoylova, Heino and Relationships, 2013).

From the description above, it can be inferred that to support Pandeglang District government programs, improving maternal health and reduce the maternal mortality rate (MMR). It can be done through increasing the prevention of complications by developing a model of assistance established on the development of community assets and participation, a model of Participatory Asset Community Development Health In Action (YUDHIA). YUDHIA model is a modification of Participatory Action Research (PAR) and the Asset Based Community Development (ABCD), which is intended to complement each other adapted to the needs, circumstances, and community participation involved in this study. YUDHIA models are expected to address issues related to the incidence of complications of pregnancy and childbirth in the community in the prevention of complications of pregnancy and childbirth (Fratidhina et al., 2017). This study was conducted to identify the aspects of the Participatory Asset Community
Development Health In Action Model (YUDHIA).

\section{METHOD}

This study used a qualitative approach. This study used the Rapid Assessment Procedure (RAP) strategy to explore how could community participation and community assets help in the prevention of complications of pregnancy and childbirth in a short time. The data were collected using a Focused Group Discussion (FGD), in-depth interviews, and observation. Triangulation was conducted to validate the results of the study and assure the results of the conversation. Focused Group Discussion (FGD) aims to see the variety of opinions and influence of culture related to community participation and the assets that also associated with the prevention behavior of pregnancy and childbirth complications.

Initially, researchers recruited several respondents by predetermined criteria, but only four women were elected as key informants to be involved in this study with an age range of 25-35 years. The discussion was guided by facilitators (Researchers) using semi-structured guidelines that had been prepared previously. In general, the time of the FGD lasted about 90 minutes. Meanwhile, the 
in-depth Interview (II) was conducted to explore the comprehensive and in-depth information related to participation and utilization of public assets in confronting complications of pregnancy and childbirth.

The clearance was obtained from the Research and Development Agency of the Regional Government of Banten Province, National Unity, and Community Protection District Office. An ethical review of the study was obtained from the Ethics Committee of the Faculty of Medicine, University of Andalas Padang.

Preliminary research was conducted as an initial assessment. In this study, researchers observed people's activity every day, behavioral health, maternal health status, behavior and public confidence, sanitation, community structure, the role of the husband, the village midwife, and health services. This preliminary study also included inculturation or blending into the everyday life of the community, such as following the Integrated Health Center (Posyandu) programs for pregnant women and joining community activities. After the preliminary study phase was successfully implemented, the next step was for the community organizing for the research agenda. At this stage, the activities undertaken were: (1) forming groups of informants, (2) Analyze the problem, and (3) formulate the problem.

\section{RESULTS AND DISCUSSION \\ Overview of Study Location}

Pandeglang district has 36 Health Centers located in every area, 9 Health Centers with nursing facilities, 58 supporting Health Centers, 51 mobile health clinics, and one hospital. For health personnel, there are 37 physicians, 14 dentists, 250 nurses, 226 non-medical health workers, and seven public health personnel.

This research was conducted in the Cimanuk District because the results of preliminary studies showed that there are 50 percent of pregnant women have a high enough risk for complications there. The danger arises because of several causes, including the pregnant women who are too young or too old, the first of pregnancy (Primavera), or the pregnancy is more than five times (Grande multipara) and anemic.

Cimanuk Subdistrict is geographically located at $06^{\circ} 28^{\prime} 16,5$ "south latitude and $106^{\circ} 00^{\prime} 00,0^{\prime \prime}$ East Longitude (Measured using GPS at the Cimanuk District Office) with the area of $23.64 \mathrm{~km}^{2}$ or $8.7 \%$ of Pandeglang area. Cimanuk Subdistrict is $10 \mathrm{~km}$ from the Capital of District 
Pandeglang, Pandeglang Subdistrict. included in the zone of the mountain foot

Cimanuk subdistrict consists of 11

villages, Kupahandap village is the

smallest village with an area of $1.51 \mathrm{~km} 2$.

In contrast, Kadubungbang village is the largest village with an area of $2.76 \mathrm{~km} 2$ or $11.68 \%$ of the total districts Cimanuk. The Cimanuk District's topography is generally a plateau with an average altitude of below $500 \mathrm{~m}$ above sea level (asl). In terms of geomorphology, the Cimanuk District is and the foot of Mount KarangPulo sari, where many springs so it becomes a major agricultural center in Pandeglang. In Cimanuk Subdistrict, nine health facilities are consisting of Health Centers, supporting Health Centers, mobile clinics, and village Health Centers (Puskesdes). Details of the distribution of health facilities are shown in Table 1.

Table1. Distribution of Health Facility in Cimanuk

\begin{tabular}{llrcrcc}
\hline No & \multicolumn{1}{c}{ Village } & $\begin{array}{c}\text { Health } \\
\text { Center }\end{array}$ & $\begin{array}{c}\text { (Supporting } \\
\text { Health } \\
\text { Center) }\end{array}$ & $\begin{array}{c}\text { Mobile } \\
\text { Clinic }\end{array}$ & $\begin{array}{c}\text { Village } \\
\text { Health } \\
\text { Center }\end{array}$ & Total \\
\hline 1 & Kadudodol & - & 1 & - & - & 1 \\
2 & Gunungdatar & - & - & 1 & - & 1 \\
3 & Gunungcupu & - & - & 1 & - & 1 \\
4 & Sekong & - & - & - & 1 & 1 \\
5 & Cimanuk & - & - & - & - & 0 \\
6 & Batubantar & 1 & - & - & - & 1 \\
7 & Rocek & - & - & 1 & - & 1 \\
8 & Kadumadang & - & - & - & - & 0 \\
9 & Dalembalar & - & - & 1 & - & 1 \\
10 & Kupahandap & - & - & - & 1 & 1 \\
11 & Kadubungbang & - & - & 1 & - & 1 \\
\hline
\end{tabular}

Source: Cimanuk Subdistrict, 2016

\section{Characteristics of Key Informants}

Key informants were four people, pregnant women at risk of complications of pregnancy and childbirth. The distribution of key informants is presented in Table 2. 
Yudhia F, Nursyirwan E, Rizanda M, Artha BD, Basic Construction Factors of

Participatory Asset Community Development Health In Action (Yudhia) Model to Prevent Complication of Pregnancy and Child-Birth

Table 2. Characteristics of Key Informant

\begin{tabular}{lccllcc}
\hline Code & Age & $\begin{array}{c}\text { Number of } \\
\text { children }\end{array}$ & Occupation & Education & $\begin{array}{c}\text { Gestation } \\
\text { (Month) }\end{array}$ & $\begin{array}{c}\text { Distance to } \\
\text { Health } \\
\text { Center } \\
\text { (kilometers) }\end{array}$ \\
\hline S1 & 32 & 3 & Housewife & $\begin{array}{l}\text { Elementary } \\
\text { School }\end{array}$ & 8 & 3 \\
\hline S2 & 28 & 1 & Housewife & $\begin{array}{l}\text { Elementary } \\
\text { School }\end{array}$ & 6 & 2 \\
\hline S3 & 26 & 2 & Housewife & $\begin{array}{l}\text { Senior High } \\
\text { School }\end{array}$ & 6 & 6 \\
\hline S4 & 34 & 2 & Labor & $\begin{array}{l}\text { Junior High } \\
\text { School }\end{array}$ & 5 & 6 \\
\hline
\end{tabular}

Source: in-depth interview 2016

Characteristics of Supporting Informants

Characteristics of supporting informants as research subjects have been interviewed are presented in Table 3.

Table 3. Characteristic of Supporting Informants

\begin{tabular}{|c|c|c|c|c|c|}
\hline Code & Age & Position & Work Period & Unit of Work & Education \\
\hline B1 & 38 & $\begin{array}{l}\text { Midwife in } \\
\text { the Health } \\
\text { Center }\end{array}$ & 12 & $\begin{array}{l}\text { Health Center in } \\
\text { Cimanuk }\end{array}$ & $\begin{array}{l}\text { Diploma } \\
\text { III }\end{array}$ \\
\hline B2 & 40 & $\begin{array}{l}\text { Coordinator } \\
\text { midwife in } \\
\text { Health } \\
\text { Center }\end{array}$ & 15 & $\begin{array}{l}\text { Health Center in } \\
\text { Cimanuk }\end{array}$ & $\begin{array}{l}\text { Diploma } \\
\text { IV } \\
\text { Midwife }\end{array}$ \\
\hline KP & 48 & $\begin{array}{l}\text { Head of } \\
\text { Health } \\
\text { Center }\end{array}$ & 15 & $\begin{array}{l}\text { Health Center in } \\
\text { Cimanuk }\end{array}$ & Doctor \\
\hline KD1 & 40 & Health Cadre & 10 & $\begin{array}{l}\text { Cimanuk } \\
\text { Subdistrict }\end{array}$ & $\begin{array}{l}\text { Junior } \\
\text { High } \\
\text { School }\end{array}$ \\
\hline KD2 & 34 & $\begin{array}{ll}\text { Head } & \text { of } \\
\text { Village }\end{array}$ & 2 & $\begin{array}{l}\text { Cimanuk } \\
\text { Subdistrict }\end{array}$ & $\begin{array}{l}\text { Senior } \\
\text { High } \\
\text { School }\end{array}$ \\
\hline SM & 40 & Headman & 4 & Labor & $\begin{array}{l}\text { Senior } \\
\text { High } \\
\text { School } \\
\end{array}$ \\
\hline DK1 & 52 & TBAs & 20 & $\begin{array}{l}\text { Cimanuk } \\
\text { Subdistrict }\end{array}$ & $\begin{array}{l}\text { Never } \\
\text { Attending } \\
\text { School }\end{array}$ \\
\hline DK2 & 58 & TBAs & 30 & $\begin{array}{l}\text { Cimanuk } \\
\text { Subdistrict }\end{array}$ & $\begin{array}{l}\text { Not } \\
\text { graduated } \\
\text { from } \\
\text { elementary } \\
\text { school }\end{array}$ \\
\hline
\end{tabular}


Thematic Analysis

Qualitative research conducted related to the model of the participatory community, including community assets, community participation, knowledge, attitudes, and behavior of complications of pregnancy, and also childbirth prevention in pregnant women obtained the research objectives that had been developed previously. The findings of the study can be described in sub-topics below.

\section{Development of Community Assets}

a. Physical assets

Physical assets are the existence of Health Centers and Integrated Health Center (Posyandu) in the area. Based on the results of in-depth interviews and FGD, to date, the TBAs and midwives felt that the assets have been running quite right. Programs conducted by the Health Center have been running well, although it deemed not optimal. To optimize those programs, the Health Center would be assisted by PONED Health Centers and community health posts.

"... The program has been running, merely perhaps not optimally match the expectation.there are some new assets here.. 1 Health Center, 1 PONED, one community health post, in Cimanuk Subdistrict ..." (B1)
Other physical assets; Integrated Health Center (Posyandu), has a function as a mediator of implementation of antenatal care. Usually, many pregnant women come to have antenatal care because they know that there will be a midwife there. To optimize the function of Posyandu related to prenatal care, midwives coordinate with TBAs to do a "massage service" when Posyandu underway.

" The coordination is through Posyandu and when we meet by chance in the street. If there were a Posyandu, sometimes I participate, but if not, occasionally pregnant women who come by themselves. Posyandu midwife usually ask pregnant women about their pregnancy interference .. "(B2)

"..We had the post for every Posyandu region. Each Posyandu has a person in charge. Posyandu should approach to the TBAs, so we'll know if anyone comes to massage in their place .. (KDI)

\section{b. Economic Assets}

Community economic asset in Cimanuk Subdistrict is good and do not become an obstacle in the prevention of complications of pregnancy and childbirth.

".. Pregnant women want to get antenatal care but not as early as possible ....Posyandu has never charge (free). Payments in Posyandu are voluntary .... If 
they do not have health insurance (BPJS or Jamkesmas), they must pay for treatment at the Health Center, even so, people still want checkups ...so economic assets is still pretty good.. " $(K P)$

\section{c. Environmental Assets}

One of the programs developed to reduce maternal mortality is Standby Village (DesaSiaga) programs. In Cimanuk, the implementation is not running well because there were no ambulances and blood donors' equipment. Nevertheless, according to the results of interviews known that until now Desa Siaga program is already running, stuff that has not to exist yet were not necessary

"... Equipment not fully support, not optimal in a sense... Already have Desa Siaga activities ....." (KD1).

".. What has not been taking place is no village ambulance, blood donor. Some families do not want to because of economic limitations, and they usually use SKTM. Desa Siaga is running ... "(KD2)

\section{d. Human Assets}

Human resources are one crucial aspect of the prevention of complications of pregnancy and childbirth (Buxton et al., 2019). In addition to health professionals (Doctors, midwives, and nurses), TBAs, and cadres are also one asset that can be a partner for health professionals if they were well trained. There are as many as 28 TBA and around 230 people active cadres. TBA's interaction with health professionals has been established. TBA no longer assists childbirths. Still, there are TBAs that are always helping childbirths with the reason they did not get to call the midwife. For such TBA, intensive coaching is needed, considering that it does increase the risk of childbirth complications. A partnership that exists between the midwife and TBA during the childbirths is in the form of midwives that assist childbirths, while TBAs do the massage and give support when the mother bears down.

".. (Human assets) ... there are 28 people TBA in the subdistrict, 230 cadres, a total of about 255 staff, and active TBA .... We are already partnered with TBA, but some of them are still helping the childbirths, for a variety of different reasons, in this case, can not be called a partner ... "(B2).

"... The partnership means cooperation between midwives and TBAs in attending childbirths. Participation in childbirth, TBA's portion is the upper part of the mother's body, massaging the mother. The midwives are the lower part of the body, helping the childbirth. By cooperating with the TBA, the works become lighter. 
Besides, TBA helps support the mother to bear down and massage her .. "(B1 / B2) While the interaction between cadres and midwives have been conducted since 2013. Cadres are actively assisting the midwives in distributing iron tablets to pregnant women. At the same time, cadres also provide education about the signs and dangers of pregnancy, as it is written in the KIA book.

"... We've been partnering since 2013, and active cadres run every month, routinely distribute Fe tablet. Facilitated with KIA book, to read the danger signs of pregnancy ..." $(K P)$

\section{Social assets}

Social and cultural characteristics in the Cimanuk District are also a concern in developing YUDHIA models construction. Socially, in women who had desired pregnancies, the family provides excellent support. The family did not provide support for the pregnancy. Interviews with midwives showed that in taking decisions related to pregnancy and childbirth, the mother should always discuss with her husband and family. So, in this case of pregnant women do not have the authority to determine what actions to take related to pregnancy and childbirth.

"... If from the beginning of pregnancy is wanted, the family will support. But if it does not,l the decision depends on her husband and family. ".. (B1 / B2)

At the time of childbirth, in addition to a midwife, many pregnant women still involve a TBA to support them. When something is not right, then the only midwife who decides to refer. In this case, the TBA only accompanies the mother.

"... Who makes the decision is a midwife. I am a TBA. Only follow them. If they say the mother should be referred, I only accompany to refer. "(D1/D2)

\section{Participation of Community}

Dimensions of Community Contribution

Community contributions and services during the childbirths are one appropriate intervention used to achieve a positive childbirth experience (Phoosuwan et al., 2020). Contributions from Healthcare workers, for example, are empathy and patience to support mothers who gave childbirth and her family. Health care workers should be able to support the mother, her partner, and her family during the childbirths (Mgawadere et al., 2019).

".. Midwife helped a lot providing socialization about pregnancy and safe childbirth.fairly high contribution of midwives reduce maternally and infant mortality .. so far midwives have sufficient skills in the implementation of the prevention of complications .." (KP) 
Results of an interview with the informant indicated that there was support from community contributions in the form of counseling by health workers (Midwives), cooperation, regular meetings of pregnant women, socialization about pregnancy myths, such as the following excerpt explanation.

".. There is a mutual help here ..many community participation such as lectures, $R W$ meetings, Posyandu, pregnant mothers would come to the Posyandu for antenatal care .." (KD1)

" Some pregnant women were coming, but there are some of them that did not want to come because of the distance and busy .. people here would love to have gathering .... Head of RT / RW ready to assist residents ....forDesaSiaga, maybe later "(KD2)

\section{Community empowerment}

Community empowerment is one of the solutions to reduce maternal and infant mortality. This approach will be especially beneficial in a remote area with minimal access to health services (Singh et al., 2017). In Cimanuk and KadubungbangSubdistrict, training for TBA is also needed to be intensified to reduce the maternal mortality rate. The indepth interview showed that TBA participation in assisting the childbirth process is quite high. According to the TBA in the District of Cimanuk and Kadubungbang, the majority of pregnant women in the region came to give childbirth and have routine antenatal care, just like the interview excerpts below:

"Yes, they check here ..give childbirth here .. because there is no certain benchmark price, and the place is not far. they are scared of midwives .. afraid of the cost and fear about the sewn they said" (DK1) "Some of them check the pregnancy here and the others in midwives ...sometimes they give childbirth here, or I come to their house ... the cost is more expensive in midwives... they can not afford... and most of them are my relatives" (DK2)

Based on the interview, it was known that TBAs include informal leader type. They have the power and authority that is respected by the people around him. The police, especially the charismatic authority (Kasmel and Andersen, 2011). Theoretically, the police can be distinguished by traditional authority, rational authority, and charismatic authority. TBAs are considered as having charismatic authority, the ability or authority specifically contained within them. Authority was held without study, but exists by itself and is an inherent culture. But some mothers prefer to be 
helped by a midwife. Recognition of pregnant women can be seen as follows:

".. Although the family recommends giving childbirth in a TBA, because I always check the pregnancy in the midwife, then I gave childbirth there, TBA was also there but just massaging me and reciting prayers ..." (S1)

"... A time to give childbirth, my mother advised me to provide delivery in the TBA because of the experience. It was painful childbirth, my husband had called the midwife to help me, but the baby still would not come out. The midwife would bring me to the hospital. But my mother forbids it, asked to call the TBA. Then my husband calls TBA .... When the TBA arrived at the door of the house, the baby was out safely ".. (S3).

The fact that people prefer to be helped by TBA during childbirth is strengthened by the statement of midwives serving in the region. The midwife said that the involvement of the TBAs in delivery is due to the cultural factors and hereditary tradition. Not the same as a midwife, TBA will give a mantra during the process so that the women who give childbirth will feel calmer.

" People always call a TBA to help birth. This caused by a matter of tradition, the TBAs will spell the mantra during childbirth to run smoothly "(S1)
Another perception that causes many TBA still helps the child birthing process is because people felt that there was still a junior midwife. They do not have the childbirth experience so deemed to be incompetent to help childbirth. To handle this, one midwife is trying to adopt the services provided by TBAs.

"I'm just partnering. It is odd if they have never given childbirth but helped the birth. We have more belief in TBAs ... I worked with TBAs. I said to the patient how much they pay for TBAs, and then I'll be at the same rate. I'll wash the clothes, massage, bath, calm the baby, and a TBA does anything I can do it "(S2)

\section{Organizing}

The commitment of healthcare workers is to implement a program of prevention of pregnancy and childbirth complications (Figueiredo et al., 2018). It is one of the DesaSiaga programs that will be discussed in this study.

"... DesaSiaga already exists but has not run optimally. No structure of $R W R T$. Some villages using self-help savings called Tabulin and Dasolin. There are villages in Kupahandap which allocate rice aid from the districts into the Dasolin. In Cimanuk village, there is also contribution per resident eg, IDR.1000,00 to the village cadres, then collected to 
DesaSiaga. Although they haven't run optimally yet, there is an effort for that. So it can help if there is some illness or maternity ..." $(K D 1)$

"..Program of prevention the complications through DesaSiaga that is being run in the Cimanuk village including home visits by health workers, cadres, community leaders, health education, eradication of mosquito larvae, garden nutrition for toddlers and sticker attachment .." (KD2)

Based on the triangulation from supporting informants know that: it can be concluded that the midwives in Pandeglang said that by working with the TBAs makes them feel their work helped or lighter. Moreover, the TBAs are usually those who are already very close to the people, so they are often the first to know if there are pregnant women. Also, sometimes people still require the presence of TBAs to help them, especially after childbirth, to help clean the house, wash the baby, and spell the mantras.

\section{CONCLUSION}

Community participation has been running with the formation of Desa Siaga, but until now, the Desa Siaga programs have not run optimally. The existence of Desa Siaga can help pregnant women, maternity, and family to save pregnant women and childbirth mothers. Partnership midwives and TBAs have been formed. Organizations were existing according to the needs of the village, along with the involvement and community participation, especially the contribution of time and effort, which is good enough.

Community's most valuable asset is the human assets in the form of partnership midwives and TBAs causing a full commitment to the needs and safety of pregnant women. In the context of a partnership between midwives with TBAs, the involvement of the midwives and TBAs in collaboration is an essential requirement for this partnership to continue well. The existence of cadre quite helpful in improving maternal and infant health, but cadres have not fully exposed to the program of childbirth planning and complications prevention. They did not know their role in the plans. In the decision to choose a childbirth attendant, most expectant mothers have independence in decision-making. Still, in case of complications and emergencies, pregnant / maternity can only surrender to the decision of the husband/family.

\section{REFERENCE}

Buxton, H. et al., 2019. 'Barriers and opportunities experienced by staff 
when implementing infection prevention and control guidelines during labor and delivery in healthcare facilities in Nigeria', Journal of Hospital Infection. Elsevier Ltd, 103(4), pp. 428-434. DOI: 10.1016/j.jhin.2019.07.018.

Figueiredo, K. M. S. et al. 2018. 'Actions of primary health care professionals to reduce maternal mortality in the Brazilian Northeast', International Journal for Equity in Health, 17(1), pp. 1-8. DOI: 10.1186/s12939-0180817-x.

Fratidhina, Y. et al. 2017. Pengembangan Model Yudhia Sebagai Pendekatan Persalinan Berbasis Aset Dan Partisipasi Masyarakat. Universitas Andalas.

Gong, J. et al. 2012. 'Maternal ethnicity and pre-eclampsia in New York City, 1995-2003', Paediatric and Perinatal Epidemiology, 26(1), pp. 45-52. DOI: $10.1111 / \mathrm{j} .1365-$ 3016.2011.01222.x.

Kasmel, A., and Andersen, P. T. 2011. 'Measurement of community empowerment in three community programs in Rapla (Estonia)', International Journal of Environmental Research and Public Health, 8(3), pp. 799-817. doi: 10.3390/ijerph8030799.

Kemenkes RI. 2019. Profil Kesehatan Indonesia 2018 [Indonesia Health Profile 2018]. Available at: http://www.depkes.go.id/resources/ download/pusdatin/profilkesehatan-indonesia/Data-danInformasi_Profil-KesehatanIndonesia-2018.pdf.

Kulkarni, B. 2016. 'Management of moderate and severe acute malnutrition in children',
Proceedings of the Indian National Science Academy, 82(5), pp. 15191528.

doi: 10.16943/ptinsa/2016/48884.

Mardianto, T. 2013. Konsep-konsep pemberdayaan masyarakat: acuan bagi aparat birokrasi, akademi, praktisi, dan peminat/pemerhati pemberdayaan masyarakat. Surakarta: Lembaga pengembangan pendidikan UNS Press.

Mgawadere, F. et al. 2019. 'There is no time for knowing each other: Quality of care during childbirth in a low resource setting', Midwifery. Elsevier B.V., 75, pp. 33-40. doi: 10.1016/j.midw.2019.04.006.

Mikkelsen, B. 2011. Metode Penelitian Partisipatoris dan Upaya Pemberdayaan: Panduan Bagi Praktisi Lapangan (CU ke-5). Yogyakarta: Yayasan Pustaka Obor Indonesia.

Pandeglang, B. P. S. K. 2016. Statistik Kesejahteraan Rakyat Kabupaten Pandeglang 2015. BPS Kabupaten Pandeglang.

Phoosuwan, N. et al. 2020. 'Intervention intended to improve public health professionals, self-efficacy in their efforts to detect and manage perinatal depressive symptoms among Thai women: a mixedmethods study', BMC Health Service Research. BMC Health Services Research, 20(138), pp. 111. doi: 10.1186/s12913-020-5007$\mathrm{z}$.

Samoylova, V., Heino, E., and Relationships, R. 2013. Empowering Social Work: Research \& Practice, Empowering Social Work: Research \& Practice. Doi: 10.31885/2018.00023. 
Singh, S. et al. 2017. 'Community participation in health services development: A systematic review on outcomes', European Journal of Public Health, 27(suppl_3), pp. 125. doi: 10.1093/eurpub/ckx187.429.

Walker, S. P., Permezel, M., and Berkovic, S. F. 2009. 'The management of epilepsy in pregnancy', BJOG: An International Journal of Obstetrics and Gynaecology, 116(6), pp. 758767 doi: 10.1111/j.14710528.2009.02141.x.

Yasa, I. G. W. M. 2012. 'Penanggulangan Kemiskinan Berbasis Partisipasi Masyarakat di Provinsi Bali', Jurnal Ekonomi dan Sosial, 1(2), pp. 8691. 